Васильченко О. А.

O.A.Vassilchenko

ВНУТРИСЕМЕЙНЫЕ ОТНОШЕНИЯ НА РОССИЙСКОМ ДАЛЬНЕМ ВОСТОКЕ (ВТОРАЯ ПОЛОВИНА ХІХ - НАЧАЛО ХХ ВВ.): СОЦИАЛЬНО-ИСТОРИЧЕСКИЙ АСПЕКТ

\title{
FAMILY RELATIONS IN THE RUSSIAN FAR EAST (SECOND HALF XIX - EARLY XX C.): SOCIOHISTORICAL ASPECT
}

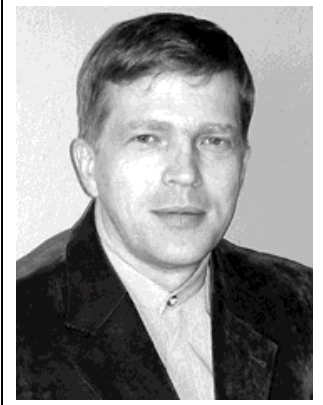

Васильченко Олег Алексеевич - доктор исторических наук, профессор кафедры «Социальная работа» Комсомольского-на-Амуре государственного технического университета (Россия, Комсомольск-на-Амуре); 84217241121. E-mail: SFknagtu@mail.ru.

Mr. Oleg A. Vassilchenko - Doctor of Historical Studies, Department of Social Work, Komsomolsk-on-Amur State Technical University (Komsomolsk-on-Amur). E-mail: SFknagtu@mail.ru

Аннотация. Охарактеризованы особенности внутрисемейных отношений дальневосточного населения. Дана оценка деятельности крестьянской общины и православной церкви в деле укрепления института семьи у восточнославянского населения. Приведены законы Российской империи, регламентирующие семейные обязанности мужа и жены.

Summary. Family relations of the Russian Far East's population are characterized. Estimation is given of the role of peasant community and the Orthodox Church in strengthening of the institute of family among East Slavonic population. The laws of the Russian Empire are described that regulated family obligations of the husband and wife.

Ключевые слова: Дальний Восток, история, семья, обязанности мужа и жены, дискриминация женщин, патриархальный порядок.

Key words: the Far East, history, family, obligations of the husband and wife, discrimination of women, patriarchal order.

\section{УДК $316.35 / 356.2$}

В Дальневосточном регионе семья как социальная система имеет свои специфические особенности, которые формировались под воздействием исторических и географических условий освоения и заселения данной территории.

По историческим меркам возраст дальневосточной семьи очень мал. Если не учитывать аборигенное население, то процесс создания и развития дальневосточной семьи активно осуществляется в последние полтора века. Основой этому послужили миграционные движения в середине XIX - начале XX века.

Новое население региона в своем большинстве составили крестьяне-переселенцы, принесшие с собой не только имущество, но и стиль, образ жизни.

Крестьяне жили в условиях натурального, полукрепостнического хозяйства. Немногочисленные в то время городские рабочие в значительной своей части тоже были выходцами из деревни, сохранившими в той или иной степени крестьянские нравственные традиции и культуру семейных взаимоотношений.

Взгляды крестьянских новоселов отражали представление российского крестьянства XIX - начала XX века о браке и семейной жизни, взаимоотношениях мужчин и женщин, которые сформировались под воздействием целого комплекса социально-экономических факторов.

Для российских крестьян одним из главных условий жизни, определявших семейный быт, являлась жизнь в деревенской общине, ставшей основой российской деревни. Она за- 


\section{Васильченко О. А.}

ВНУТРИСЕМЕЙНЫЕ ОТНОШЕНИЯ НА РОССИЙСКОМ ДАЛЬНЕМ ВОСТОКЕ

(ВТОРАЯ ПОЛОВИНА ХІХ - НАЧАЛО ХХ ВВ.): СОЦИАЛЬНО-ИСТОРИЧЕСКИЙ АСПЕКТ

нималась управлением и регулированием поведения крестьян. При этом общине был свойственен строжайший социальный контроль, цензура нравов, от которого нельзя было укрыться. Она же осуществляла надзор за выполнением норм семейного права, соблюдение которых было обязательным для всех.

В российской деревне взаимоотношения в среде односельчан носили публичный характер. Брачные и семейные отношения не были исключением из этого правила. Так, в свадьбе принимала участие вся община. На ее сходах разбирались семейные конфликты, наказывались розгами провинившиеся.

Заключение брака являлось одним из главных событий в жизни крестьянина, показателем его порядочности, общественного веса и материального положения. Только после этого крестьянин становился полноправным членом сельской общины.

Для российских крестьян вступление в брак являлось моральным долгом каждого члена крестьянского общества. По существовавшим понятиям, не женились только неполноценные люди. Неженатые мужчины становились объектами насмешек в деревенской среде, не являлись исключением и незамужние женщины.

Негативное отношение односельчан к людям, живущим вне брака, было обусловлено экономическими и правовыми различиями в жизни женатых и холостых (незамужних) членов сельской общины.

Например, холостяк не мог рассчитывать на получение земельного надела - основного источника для своего существования. По мнению крестьян, женщина без мужа не имела самостоятельной ценности.

Крестьянская семья отличалась верностью сторон в браке. Прочность семей гарантировалась строгими взглядами сельчан на неверность супругов, убежденностью в неразрывности брачных уз. Неверных в браке ждал общественный позор. Рождение детей вне брака строго осуждалось. Внебрачные дети не получали помощи от общины и государства. Развод был почти невозможен и рассматривался как тягчайший грех, поэтому разводы в деревнях были большой редкостью. Укреплению семейных уз способствовала православная церковь, влиявшая на формирование общественного мнения.

Но иногда браки расторгались. Причиной этому чаще всего служила смерть одного из супругов. Вдовство считалось в среде крестьян божьим наказанием. При этом второй брак вдовых не осуждался, третий порицался из-за религиозных предрассудков.

Встречались союзы, вовремя не освященные официальной православной церковью по причине отсутствия священника. Нередкими были случаи венчания, происходившего много лет спустя после заключения брака, когда у супругов уже были дети.

Взаимоотношения супругов регламентировались законом, в соответствии с которым муж «обязан любить жену свою как собственное свое тело, жить с нею в согласии, уважать, защищать, извинять ее недостатки и облегчать ее немощи. Он обязан доставлять жене пропитание и содержание по состоянию и возможности своей» [2]. Она «обязана повиноваться мужу своему как главе семейства, пребывать к нему в любви, почтении и в неограниченном послушании, оказывать ему всяческие угождения и привязанность, как хозяйка дома» [3].

Следует отметить тяжелое положение женщины, дискриминация которой была закреплена законодательством. По существовавшим законам, женщина не имела права голоса при выборах в местные органы самоуправления. На сельские сходы крестьянки допускались только в случае болезни или отсутствия их мужей. Тяжелый физический труд, рождение многочисленных детей приводили к истощению здоровья и высокой смертности среди женщин.

Семейное право отражало наличие больших неразделенных крестьянских семей патриархального или полупатриархального типа, а также малых семей.

Большая семья обычно состояла из 2-4 семей женатых братьев, живущих вместе. Насчитывала она 20-40 человек нескольких поколений [1]. Члены семьи вели общее хозяйство, сообща владели имуществом. Выбор главы семьи определялся его умением вести хозяйство. Обычно главой семьи был отец, старший сын при живом отце, иногда дед. Глава семьи выступал как посредник в отношениях большой семьи и земельного общества. Он ведал всеми работами, семейным бюджетом. Взаимоотношения и распорядок в семье регламентировались обычным правом, гражданскими и церковными установлениями. Блюстителем бытового уклада также являлся глава семьи. Все беспрекословно подчинялись ему, соблюдая жесткий патриархальный порядок. 


\section{Учёные записки \\ Комсомольского-на-Амуре государственного технического университета}

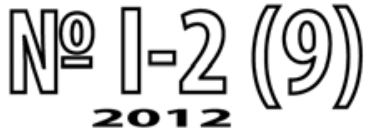

Семья скреплялась нравственным авторитетом старших, хотя нередки были случаи деспотизма в поведении главы семьи. Беспрекословное подчинение сыновей было обусловлено экономическими причинами, так как в случае неподчинения они могли лишиться права на полагавшуюся им часть имущества семьи.

Весь порядок в доме определялся главной хозяйкой. Распределение работы по дому, назначение невесток на понедельное дежурство (приготовление пищи для семьи в течение недели), наделение всех остальных домочадцев домашней работой в зависимости от возраста и пола - все это входило в ее обязанности.

Особенно трудной была жизнь невесток, имевших многочисленные обязанности и никаких прав. Они могли распоряжаться только своим приданным, не имели прав на общесемейное имущество.

Главный смысл жизни крестьянской семьи - труд, в который вовлекались все члены семьи, начиная с 10-12 лет. На Дальнем Востоке сельскохозяйственный труд был еще более тяжелым, так как его осложняли суровые природные условия.

Разделы больших семей стали частым явлением в начале XX века. При семейных разделах у крестьян соблюдались права членов семьи. Обособление отдельной семьи в новое хозяйство происходило путем деления «имения», в каждой части которого оставалось все необходимое для ведения хозяйства.

Малые семьи представляли собою простые по составу родственные общности, состоящие из 6-8 человек. Такая форма семьи начинает выступать как производственный организм, наиболее целесообразный в новых условиях хозяйствования.

Изменение домашнего уклада происходило по многим причинам. Немаловажную роль в этом сыграл отход крестьян в города. Нарастающее влияние города и городской культуры сказывалось на всей общественной и семейной жизни в деревне.

Малой семье, состоящей из представителей 2-3-х поколений, были свойственны менее деспотичные внутрисемейные взаимоотношения. Более независимой становилась женщина. Начала исчезать «забитость» младшего поколения. Ослабевала власть старшего в семье. Но при всех происходящих изменениях в малых семьях еще сохранились половозрастное разделение труда и подчиненное положение женщин по отношению к мужчинам, поддерживаемое церковью и закрепленное юридическими актами.

Однако незыблемым оставалось отношение к старикам, которые пользовались уважением и почетом в крестьянской среде. Забота о пожилых людях была одной из неукоснительных норм жизни в сельской общине.

Согласно жизненным правилам, сын должен был содержать престарелых родителей. Дочь ухаживала за ними и оказывала моральную поддержку. В случае нерадивости детей крестьянский сход и официальное право воздействовали на них. При этом в ход шли штрафы, общественное мнение и даже аресты на несколько дней.

Таким образом, характеризуя внутрисемейные отношения, сложившиеся на Дальнем Востоке в среде сельских жителей, необходимо отметить живучесть патриархальных порядков.

Развитие капитализма на Дальнем Востоке дало возможность сельскому населению получать дополнительные заработки, которые значительно превышали доход от сельскохозяйственной деятельности. Был востребован и женский труд, что, в свою очередь, способствовало изменению положения женщины в семье. Она получила возможность обеспечить себе определенную экономическую самостоятельность, вследствие чего стал изменяться ее статус.

\section{ЛИТЕРАТУРА}

1. Российский государственный архив Дальнего Востока (РГИА ДВ). Ф. 702. - Оп. 1. - Д. 207. Л. 53.

2. Свод законов гражданских. Кн. І. О правах и обязанностях семейственных. - СПб., 1900. - Ст. 106.

3. Свод законов гражданских. Кн. І. О правах и обязанностях семейственных. - СПб., 1900. - Ст. 107. 